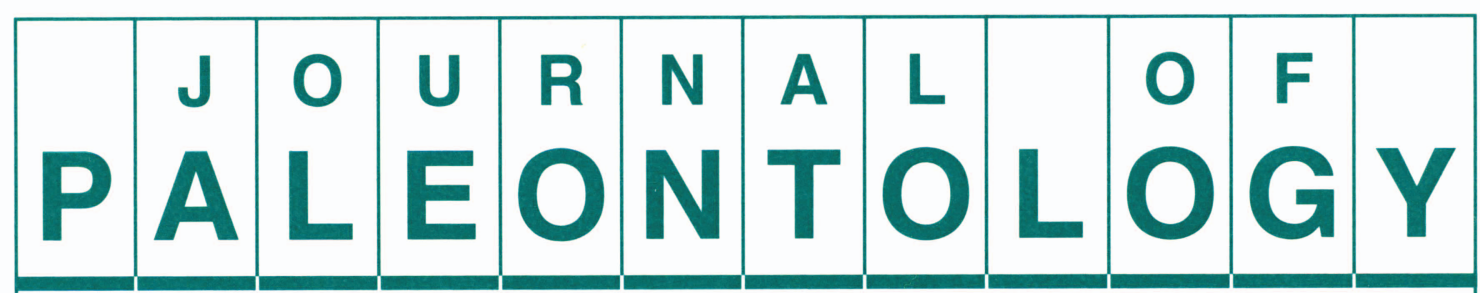

FOSSIL MARINE VERTEBRATES FROM THE LOWERMOST

GREENHORN LIMESTONE (UPPER CRETACEOUS:

MIDDLE CENOMANIAN) IN SOUTHEASTERN COLORADO

KENSHU SHIMADA, BRUCE A. SCHUMACHER, JENNIFER A. PARKIN, AND JACLYN M. PALERMO

THE PALEONTOLOGICAL SOCIETY MEMOIR 63 
Memoirs of The Paleontological Society are occasional publications consisting of monographs and symposia that are too extensive for publication in the Journal of Paleontology as part of the regular issues. Ordinarily, memoirs are published as supplements to a regular issue of the Journal. Inquiries concerning submittal of manuscripts for inclusion in the Memoir Series may be made to the Editors of the Journal of Paleontology.

For information on cost and availability of back numbers of the Memoir Series, please contact: SEPM Business Office, 1731 East 71 st St., Tulsa, OK 74136-5108, for numbers 1 (1968) through 16 (1985) or Journal of Paleontology, P.O. Box 1897, Lawrence, KS 66044-8897, jps@allenpress.com, for number 17 (1986) and following.

The JOURNAL OF PALEONTOLOGY (ISSN 0022-3360) is published bimonthly by the Paleontological Society, 810 East 10th St., Lawrence, KS 66044, USA. Dues and subscriptions for members of The Paleontological Society are $\$ 65$ per year. Subscription price is $\$ 110$ per year. Periodical postage paid at Lawrence, KS. For information on prices of back issues of the JOURNAL, please contact: SEPM Business Office, P.O. Box 4756, Tulsa, OK 74159, for volumes 1 (1927) through 59 (1985) or Paleontological Society Business Office, P.O. Box 1897, 810 East 10th St., Lawrence, KS 66044-8897, for volumes 60 (1986) and following.

Communications about the JOURNAL, notices, subscriptions, rates, changes of address, and nonreceipt of preceding numbers should be addressed to: JOURNAL OF PALEONTOLOGY Subscriptions Office, P.O. Box 1897, 810 East 10th St., Lawrence, KS 66044-8897, U.S.A., jps@allenpress.com. Claims for nonreceipt of preceding numbers must be submitted within three months (six months if foreign) of the date of publication in order to be filled gratis. Communications about membership and requests for blanks for nomination of new members in The Paleontological Society should be directed to the Secretary: Roger D. K. Thomas, Department of Earth and Environment, Franklin \& Marshall College, P.O. Box 3003, Lancaster, PA 17604-3003.

\author{
Address manuscripts to: \\ Editors, Journal of Paleontology \\ Department of Geology \\ 121 Trowbridge Hall \\ University of Iowa \\ Iowa City, IA 52242-1379 \\ fossils@uiowa.edu
}

Editors for the Journal are Jonathan Adrain, Christopher A. Brochu, and Ann F. Budd, Department of Geoscience, University of Iowa, Iowa City, IA 522421379. Associate editors are: Jason S. Anderson, University of Calgary, janders@ucalgary.ca; Laurie C. Anderson, Louisiana State University, laurie@geol.lsu. edu; Daniel B. Blake, University of Illinois, dblake@uiuc.edu; Robert L. Carroll, McGill University, robert.carroll@mcgill.ca; Keith Dewing, Geological Survey of Canada, kdewing@NRCan.gc.ca; William A. DiMichelle, Natural Museum of Natural History, Dimichelle.Bill@nmnh.si.edu; William P. Elder, Lafayette, California, chronovision@comcast.com; Robert J. Elias, University of Manitoba, eliasrj@Ms.UManitoba.CA; Michael Engel, University of Kansas, msengel@ u.edu; John R. Groves, University of Northern Iowa, John.Groves@uni.edu; Steven J. Hageman, Appalachian State University, hagemansj@ appstate.edu; Peter J. Harries, University of South Florida, harries@chuma.cas.usf.edu; Martin J. Head, Brock University, mhead@brocku.ca; Eric Hilton, Field Museum of Natural History, ehilton@fieldmuseum.org; Stephen A. Leslie, University of Arkansas, saleslie@ualr.edu; Richard Lupia, University of Oklahoma, rlupia@ou.edu; Mike Melchin, St. Francis Xavier University, Canada, mmelchin@stfx.ca; Brian Pratt, University of Saskatchewan, brian.pratt@usask.ca; Eric Scott, San Bernardino County Museum, escott@sbcm.sbcounty.gov; James Sprinkle, University of Texas, echino@mail.utexas.edu; Steve Westrop, University of Oklahoma, swestrop@ ou.edu; David M. Work, Maine State Museum; david.work@maine.gov.

The JOURNAL OF PALEONTOLOGY is printed offset by Allen Press, Inc., Lawrence, KS 66044.

Copyright (C) 2006, The Paleontological Society
ALLEN PRESS, INC., LAWRENCE, KANSAS

\section{COPYRIGHT STATEMENT}

The appearance of the code at the top of the first page of an article in this journal indicates the copyright owner's consent that copies of the article may be made for personal or internal use, or for the personal or internal use of specific clients. This consent is given on the condition, however, that the copier pay the stated per copy fee through the Copyright Clearance Center, Inc., P.O. Box 765, Schenectady, New York 12301, for copying beyond that permitted by Sections 107 or 108 of the U.S. Copyright Law. This consent does not extend to other kinds of copying, such as copying for general distribution, for advertising or promotional purposes, for creating new collective works, or for resale.

(2) This paper meets the requirements of ANSI/NISO Z39.48-1992 (Permanence of Paper). 